\title{
Mineralisation potential mapping for ophiolite- hosted volcanic massive sulphide (VHMS) deposits, Troodos Ophiolite, Cyprus
}

\author{
S.M. Jowitt \\ University of Leicester, Department of Geology, University Road, Leicester, LE1 2HD, UK \\ (smj9@leicester.ac.uk) \\ F.M. McEvoy, J. P. Williamson, L. Bateson, J. Naden, A. G. Gunn \\ British Geological Survey, Kingsley Dunham Centre, Keyworth, Nottingham, NG12 5GG, UK \\ S. Nicolaides \\ Geological Survey Department, Ministry of Agriculture and Natural Resources, 1415, Nicosia, Cyprus
}

\begin{abstract}
Data from a variety of sources can be used to generate realistic exploration targets for VHMS mineralisation in the Troodos ophiolite, Cyprus. This project used a weights of evidence approach with new data sources, in conjunction with older legacy data, to define areas of high mineralisation potential and targets for future exploration work. The final prospectivity map, identifying areas of low, medium and high mineralisation potential, defined eight areas with high mineralisation potential. Three of these areas have been outlined as possible targets for future exploration due to their size, lack of previously known mineral occurrences, and proximity to known mineral occurrences and mining districts on Cyprus.
\end{abstract}

Keywords Spatial data modelling, ArcSDM, massive sulphide, weights of evidence, Cyprus

\section{Introduction}

Mineralisation potential or prospectivity mapping is a digital extension to traditional geochemical, geophysical and geological exploration methodologies, replacing the older, nonreproducible light-table method of overlaying data. Mineralisation potential maps are constructed using statistical modelling techniques (e.g. weights of evidence, fuzzy logic) and use mineral deposit models and spatial digital data. Mineral deposit models are a summary of the state of knowledge about a given mineral deposit. Two types of deposit model are encountered (i) empirical (descriptive), here, various attributes such as host-rock lithology, deposit form (vein, stockwork), alteration, ore mineralogy etc. are considered to be essential to the model, even though their various relationships may be unknown and (ii) theoretical (genetic), where mineral deposit attributes are interrelated through fundamental mineralisation concepts such as fluid chemistry, temperature and metal precipitation mechanisms (Cox and Singer 1986). The best are, however, an amalgamation of empirical information and genetic concepts-a typical example would be that developed by Hedenquist et al. (1996) for epithermal mineralisation. The mineral deposit model controls the selection of the most appropriate input data themes and statistical methods are used to integrate various data layers to produce the mineral potential map.

\section{Methodology}

The mineral deposit model for cupriferous mineralisation in the Troodos ophiolite was created from a literature review of Cyprus and other VHMS deposits. Its essential parameters are:

1. Deposits are associated with spreading centres found at ocean ridges and oceanic arcs. They occur in the submarine environment and are controlled by fault systems and grabens. Host rocks are mafic-dominated extrusive lavas of variable age.

2. Deposit form is as massive sulphide lenses, disseminations and stockworks with stratigraphy, feeder structures and alteration envelopes controlling ore distribution.

3. Close to mineralisation, alteration comprises pyrite, sericite, chlorite and silica, whilst away from mineralisation, alteration is dominantly argillic, propylitic or carbonitic. 


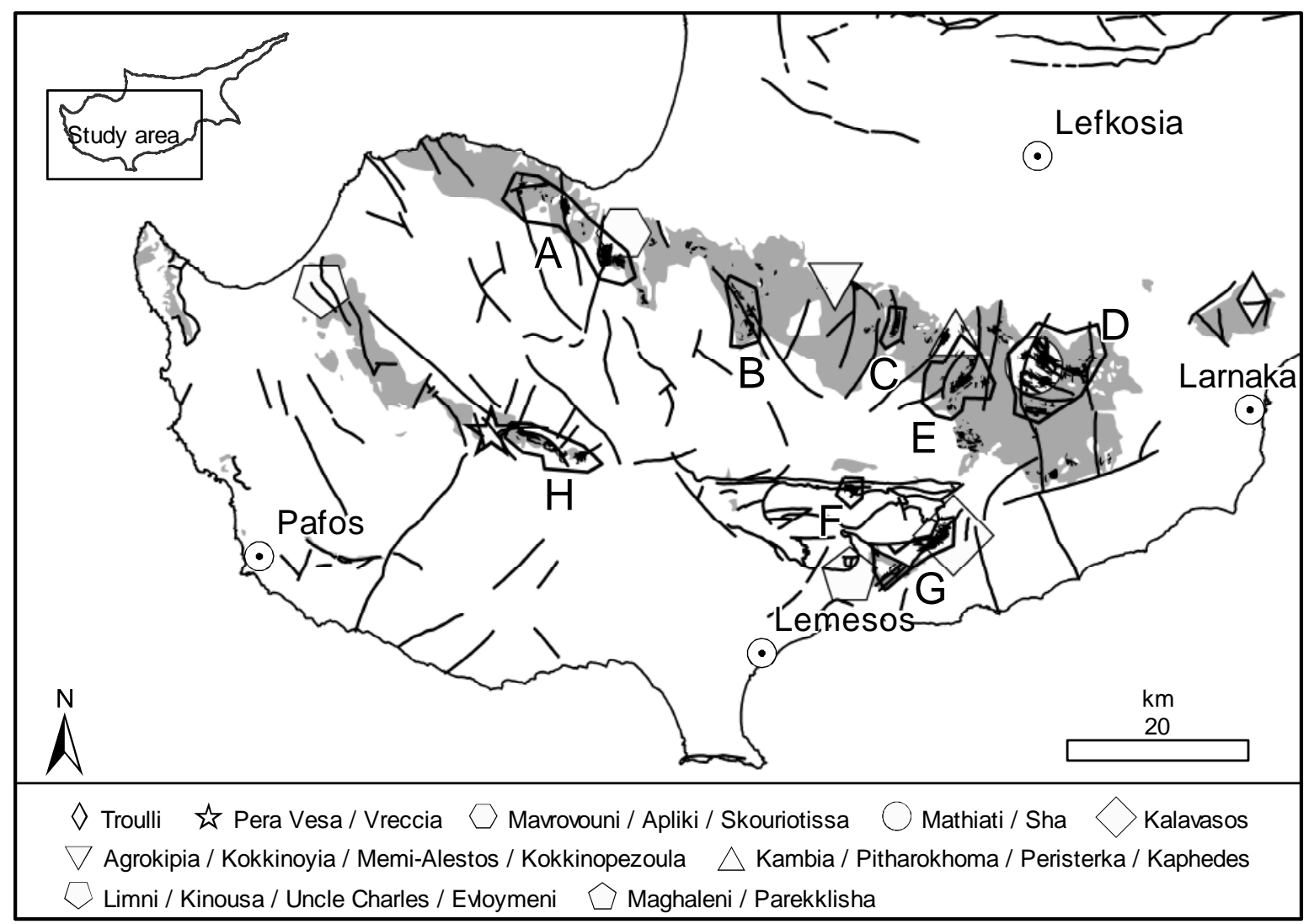

Figure 1. Prospectivity map for VHMS mineralisation in Cyprus, showing mining districts (symbols), the ophiolite crustal sequence (grey) and major faults. Lettered areas enclose zones of high mineral potential are indicated by polygons labelled A-H.

Digital geology (1:250 000) for the analysis was provided by the Geological Survey Department, Cyprus. Other available digital data were ASTER satellite imagery, digital elevation models and regional gravity (Gass and Masson-Smith, 1963). In addition, legacy map data $(1: 31,680)$ were scanned and georeferenced to digitise mineral occurrences, gossan locations and small-scale faults. The satellite data were processed to give a single tiled image for the whole island and parameters extracted to highlight relative mineralisation-related alteration intensity (Sabins, 1999).

Geochemical data for the study area is available and has been incorporated into the GIS, but spatial coverage was limited and therefore it was not used in the prospectivity analysis. Similarly, geophysical data in the form of low and high-resolution airborne magnetic surveys were not used in this regional study. However, future mineralisation potential mapping at the deposit and district scales will make use of these data. Initial investigation of the magnetic data, in particular, has highlighted a number of subsurface lineaments that relate closely to mineral deposits and could be of further use in mineral potential mapping on a more localised scale than the regional analysis presented here.

The following exploration model, which only utilises available data, was developed:

1. Deposits are typically fault-associated and in some cases these have acted as preferential hydrothermal fluid conduits.

2. Economic deposits can be capped by gossans and are commonly associated with umber, gold and ochre deposits.

3. Alteration assemblages identified using a Portable Infrared Mineral Analyser were used to ground-truth ASTER imagery to indicate zones of mineralisation-associated alteration.

4. Deposits are preferentially associated with specific lithological units and contacts that may represent hiatuses in magmatism.

5. Mineralisation is associated with regional Bouguer anomaly values between 146.7 and $166.7 \mathrm{mGal}$.

The process of binary weights-of-evidence prospectivity analysis involved converting (generalising) individual data themes (e.g. fault, geological and geophysical maps) into binary maps 
Table 1. Summary of exploration criteria used in the prospectivity analysis and their occurrence in new target areas. $\mathbf{\square}=$ Area prospective according to dataset $(\mathrm{M}=$ missing data), * = Formation present in area (italics represent prospective geological units). Refer to Figure 1 for the location of prospective areas.

\begin{tabular}{|c|c|c|c|c|c|c|c|c|c|c|}
\hline \multicolumn{3}{|l|}{ Area } & A & B & $\mathbf{C}$ & $\mathbf{D}$ & $\mathbf{E}$ & $\mathbf{F}$ & $\mathbf{G}$ & $\mathbf{H}$ \\
\hline \multicolumn{3}{|c|}{ Number of mineral occurrences per area } & 7 & 7 & 6 & 13 & 5 & 7 & 13 & 2 \\
\hline \multirow{13}{*}{ 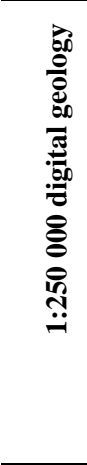 } & \multicolumn{3}{|c|}{ Alluvium - Colluvium } & & & * & & & & \\
\hline & \multicolumn{2}{|c|}{ Fanglomerate } & & * & & & $*$ & & & \\
\hline & \multicolumn{2}{|c|}{ Pakhna Formation } & & & & & & & & $*$ \\
\hline & \multicolumn{2}{|c|}{ Lefkara Formation } & & & $*$ & & & & & * \\
\hline & \multicolumn{2}{|c|}{ Perapedhi Formation } & & & & * & & & & \\
\hline & \multicolumn{2}{|c|}{ Lava and Volcaniclastic Sediments } & & & & & & $*$ & $*$ & \\
\hline & \multicolumn{2}{|c|}{ Lavas and Volcaniclastic Sediments } & & & $*$ & & & $*$ & * & * \\
\hline & \multicolumn{2}{|c|}{ Upper Pillow Lavas } & $*$ & * & & $*$ & $*$ & & & \\
\hline & \multicolumn{2}{|c|}{ Lower Pillow Lavas } & $*$ & $*$ & $*$ & $*$ & $*$ & $*$ & * & * \\
\hline & \multicolumn{2}{|c|}{ Basal Group } & $*$ & $*$ & $*$ & $*$ & $*$ & $*$ & $*$ & $*$ \\
\hline & \multicolumn{2}{|c|}{ Sheeted Dyke Complex } & $*$ & & $*$ & & & $*$ & $*$ & $*$ \\
\hline & \multicolumn{2}{|l|}{ Gabbro } & & & & & & $*$ & $*$ & \\
\hline & \multicolumn{2}{|c|}{ Intrusive Plutonic rocks } & & & $*$ & & & & & $*$ \\
\hline \multicolumn{3}{|c|}{ 1:250,000 Fault Data } & घ & घ & 口 & घ & घ & 口 & a & 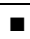 \\
\hline \multicolumn{3}{|c|}{ 1:31,680 Fault Data } & - & घ & - & - & - & - & - & घ \\
\hline \multicolumn{3}{|c|}{ Bouguer Gravity Anomaly } & & & & $\bar{M}$ & घ & - & घ & घ \\
\hline \multicolumn{3}{|c|}{ Gossan Occurrence Data } & घ & घ & घ & - & - & - & - & घ \\
\hline \multicolumn{3}{|c|}{ Lower-Upper Pillow Lava Contact } & घ & घ & $\mathbf{\square}$ & घ & & & & \\
\hline \multirow{2}{*}{\multicolumn{3}{|c|}{$\begin{array}{l}\text { Lower Pillow Lava-Basal Group Contact } \\
\text { Basal Group-Sheeted Dyke Contact }\end{array}$}} & घ & & a & $\mathbf{\square}$ & घ & घ & $\mathbf{\square}$ & घ \\
\hline & & & - & & a & & - & - & $\mathbf{\square}$ & घ \\
\hline \multicolumn{2}{|c|}{ Satellite } & $\mathbf{E}-\mathbf{W}$ & घ & & & - & 田 & - & & \\
\hline \multicolumn{2}{|c|}{ Lineations } & NW-SE & - & & & & & & - & घ \\
\hline \multicolumn{3}{|c|}{ Landsat TM Band Ratio Image } & - & - & & & & 口 & $\square$ & \\
\hline \multirow{6}{*}{\multicolumn{2}{|c|}{ 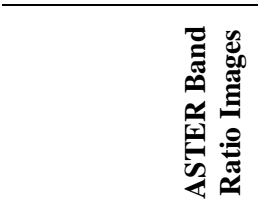 }} & $1 / 3$ & & 口 & & & - & & - & \\
\hline & & $1 / 5$ & & घ & & & घ & & & \\
\hline & & $2 / 3$ & & घ & & घ & & घ & - & \\
\hline & & $2 / 5$ & & घ & ש & ! & ש & ש & घ & \\
\hline & & $4 / 5$ & & घ & घ & घ & घ & घ & घ & \\
\hline & & $6 / 1$ & घ & घ & & घ & & & घ & $\square$ \\
\hline
\end{tabular}

that indicate prospective and unprospective areas. For the geology, this was carried out by statistically analysing the spatial association between points of known mineralisation (disused and working mines, prospects) and the various rock units depicted on the geological map. This simplifies the map into units associated with mineralisation and units that are not. Similarly, the association between faults and mineralisation was examined. Because faults are lines, they are given additional thicknessesbuffers-to enable the definition of the spatial extent of their association with mineralisation. A series of buffers are set at regular intervals of, say, $100 \mathrm{~m}$ around each fault. The analysis procedure then calculates the distance where the spatial association between faults and mineralisation breaks down. This distance is then used to create a binary map of thickened faults, where the thickness is defined by the extent of the spatial relationship between the dataset and mineralisation. Likewise, binary maps can be created for a variety of other parameters, such as geological contacts and satellite lineaments.
The procedure of generalisation, as well as simplifying data to binary maps, also calculates how prospective each theme is. When generalisation is complete, the individual binary map themes and their associated prospectivity weightings are integrated to produce the final prospectivity map. For detailed descriptions of the statistical theory behind the methodology and use of the software see Tangestani and Moore (2001) and Kemp et al. (2001).

\section{Results}

The final prospectivity analysis (Figure 1), using ArcView $^{\mathrm{TM}}$ and the Spatial Data Modeller extension (Kemp et al., 2001), was undertaken using seventeen data themes (Table 1). It identified eight areas of high mineral potential, all located within $10 \mathrm{~km}$ of the boundary between the Troodos ophiolite and the autochthonous sedimentary cover sequences draping the ophiolite. The exploration criteria used in the prospectivity analysis are listed in Table 1. 


\section{Discussion}

Areas with high mineral potential in Figure 1 are all related to clusters of known mineral occurrences. However, areas with large numbers of mineral occurrences may indicate that reserves have already been exploited. Area $\mathrm{H}$, and the northern extension of area A, located within the 1:31,680-scale mapping area and with few known mineral occurrences, are more attractive targets with little mining history. Area D is also worthy of note. It is large in size (approximately 10 by $10 \mathrm{~km}$ ) and includes known mineralisation at some localities. Although some of these have been worked, it may indicate prospectivity in adjacent regions with sedimentary cover.

In contrast, the known Troulli and LimniKinousa-Uncle Charles-Evloymeni (LKUCE) mining districts are indicated as non-prospective (Figure 1). For these areas, this may be because they are not covered by the 1:31,680-scale geological mapping. Therefore, as three major exploration themes-high-resolution geology, structure and gossan distribution-are absent over these two areas, they would not be indicated as prospective by a weights-of-evidence approach. In this instance, a fuzzy logic analytical methodology may be more appropriate.

Though most of the ASTER and Landsat band ratio images seem unprospective (Table 1 ), the tiled ASTER image does appear to highlight hydrothermal pathways in the sheeted dyke complex. In the imagery, these are visible as distinct linear structures that are coincident with lineaments defined by the airborne magnetic data and are also related to linear arrays of gossans. Further analysis of individual ASTER images, rather than the single tiled image, along with further PIMA ground-truthing is required to fully assess the significance of these trends.

\section{Conclusions}

Mineralisation potential mapping has identified eight separate areas of high mineral potential. The areas are located at or within $10-\mathrm{km}$ of the boundary between the Troodos ophiolite and the autochthonous sedimentary cover sequences. Areas $\mathrm{A}, \mathrm{C}$ and $\mathrm{H}$, and to a limited extent area $\mathrm{D}$ are considered to be the most prospective. These include relatively few mineral deposits, but have comparatively large areas of high mineral potential, indicating unexploited ground with the correct characteristics for massive sulphide and stockwork mineralisation. Though not indicated directly, buried deposits in areas overlain by sediments but adjacent to areas of high mineral potential should also be considered, and may be highlighted by future more detailed prospectivity mapping that includes the recently obtained magnetic and geochemical data.

\section{Acknowledgements}

This work is part of a collaborative research programme between the Geological Survey Department (GSD), Cyprus and the British Geological Survey (BGS) and is funded by the Government of the Republic of Cyprus. The Hellenic Mining Company Ltd, Eastern Mediterranean Minerals (Cyprus) Ltd. and Oxiana Resources NL are also thanked for access to a variety of proprietary information. Permission to publish for JN, LB, FMM, JPW \& AGG is by the Director, BGS, NERC, UK and for SN by the Director, GSD, Cyprus.

\section{References}

Cox DP and Singer DA (1986). Mineral deposit models. Reston, VA, United States, U. S. Geological Survey.

Gass IG, \& Masson-Smith SD. (1963). The geology and gravity anomalies of the Troodos Massif, Cyprus. Philosophical Transactions of the Royal Society London, Series A: Mathematical and Physical Sciences, 255, 417467.

Hedenquist JW, Izawa E., Arribas A, White NC. (1996) Epithermal gold deposits; styles, characteristics, and exploration. Resource Geology Special Publication 1, Society of Resource Geology. Tokyo, Japan, 70p.

Kemp LD, Bonham-Carter GF, Raines GL \& Looney, CG. (2001) Arc-SDM: ArcView extension for spatial data modelling using weights-of-evidence, logistic regression, fuzzy logic and neural network analysis (software). http://ntserv.gis.nrcan.gc.ca/sdm/.

Sabins FF. (1999) Remote sensing for mineral exploration. Ore Geology Reviews, 14, 157-183.

Tangestani MH \& Moore F (2001) Porphyry copper potential mapping using a weights-of-evidence model in a GIS, northern Shahr-e-Babak, Iran. Australian Journal of Earth Sciences, 48, 695701. 